\title{
EchoGéo
}

45 | 2018

Déclinaisons géographiques du changement social en Iran

\section{Geographic expressions of social change in Iran} Introduction

Amin Moghadam, Mina Saïdi-Sharouz and Serge Weber

OpenEdition

Journals

Electronic version

URL: https://journals.openedition.org/echogeo/17780

DOI: $10.4000 /$ echogeo. 17780

ISSN: 1963-1197

Publisher

Pôle de recherche pour l'organisation et la diffusion de l'information géographique (CNRS UMR 8586)

Electronic reference

Amin Moghadam, Mina Saïdi-Sharouz and Serge Weber, "Geographic expressions of social change in Iran", EchoGéo [Online], 45 | 2018, Online since 05 September 2019, connection on 11 August 2021. URL: http://journals.openedition.org/echogeo/17780 ; DOI: https://doi.org/10.4000/echogeo.17780

This text was automatically generated on 11 August 2021.

EchoGéo est mis à disposition selon les termes de la licence Creative Commons Attribution - Pas d'Utilisation Commerciale - Pas de Modification 4.0 International (CC BY-NC-ND) 


\title{
Geographic expressions of social change in Iran
}

\author{
Introduction
}

Amin Moghadam, Mina Saïdi-Sharouz and Serge Weber

1 Publishing a thematic issue of a geography journal on Iran in the second half of the 2010s is both a fascinating endeavor and a challenge. Over the past few years, the Islamic Republic of Iran has been the focus of much attention. H. Rohani's election for President in 2013 brought the moderates back into power after two mandates with conservative M. Ahmadinejad. The reopening of multilateral negotiations on Iran's infamous nuclear program was interpreted as a thaw in US-Iran relations, leading up to the Geneva agreement in 2015 which arranged for a gradual lift of international economic and diplomatic sanctions against the country.

\section{International sanctions: an key factor for Iran's social barometer}

2 These sanctions are of course an essential factor for whoever investigates Iran's society and human geography. Initiated in the wake of the 1979 revolutions, these international sanctions were in turn attenuated and reinforced. However, their constant presence, in particular during the 1980s and the 2010s when they were at their most drastic, has had a continued influence on all aspects of economic, social and everyday life (Coville, 2000). Their considerable toughening in the mid-2000s has aggravated the country's isolation, as many Western businesses that contributed to entire sectors of activities left the country, and international trade, both import and export, collapsed. As the country was excluded from SWIFT (Society for Worldwide Interbank Financial Telecommunication, the inter-banking system that facilitates international payments), the Islamic Republic found itself in a difficult situation for the payment of international transactions as well as for its monetary policy. International economic sanctions contributed to aggravating inequalities: although the poverty rate 
has dropped continually since the early 1980s, the income gap between classes has grown (Salehi-Isfahani, 2017).

3 As for diplomatic sanctions, they dramatically limited the possibility for Iranians to travel outside of Iran. Visa policies were toughened by many countries, at a time when trade relies more than ever on foreign travel (Moghadam et Weber, 2015; MohabbatKar, 2015). The country's transnational dimension is essential to understand contemporary Iran: a reminder that international mobility to and from Iran - including by the group traditionally referred to as the Iranian "diaspora", although this group is very vaguely and kaleidoscopically defined - plays an important part in Iranian society. A significant share of the researchers who work on Iran have done at least one study trip abroad, considering the share of Iranians in international student and young graduate mobility (Naficy, 1993; Colby, Friedlander and Kelley, 1993; Adelkhah, 2001; Moghadam, 2016). As is always the case in situations of embargo, alternative circulation channels have been maintained or developed with countries that did not side clearly with the USA and its allies. Circulation flows were reconfigured towards new destinations and informal channels developed. These alternative channels of communication with the world can be observed both in the upper and lower classes, in the formal and informal sectors, involving countries as diverse as China and Malaysia as well as bordering countries such as Turkey or the United Arab Emirates.

The announcement of the lift of the sanctions after 2016 raised a lot of interest in many countries' business and cooperation spheres. A wave of publications - both academic and for the wider public - emerged, describing current affairs in Iran and documenting in particular recent transformations in the social, economic and political spheres, in a country considered a regional power and located between the Middle East and Central Asia (Djalili and Kellner, 2016). This perspective opened up potential for development through direct foreign investment and tourism. International tourism began to grow again, and many businesses that had left the country began to return and reactivate joint-ventures that had been interrupted by the reinforcement of sanctions. However, after the election of D. Trump in 2017, the USA administration's toughening towards Iran slowed down the lift of sectorial sanctions, and the USA backed out of its commitments in May 2018. In this context, the Iranian population is kept waiting, and suffers from the economic asphyxia caused by this turnaround. The reactivation by Donald Trump of G.W. Bush's simplistic arguments in an even more caricatural mode has forced the Iranian authorities and part of the country's public opinion to promote discourses of increased defiance towards the USA and their partners, and to reactivate a form of nationalism that had dwindled in recent years. This does not take away from the fact that for most Iranians, opening up to the rest of the world and being able to travel and trade freely remains a crucial but hard to implement necessity.

The call for contributions for this issue, launched in 2015-2016, stemmed from our assumption that the scheduled lift of sanctions would go along with a revival of social science research on the new faces of Iranian society, the emergence of new economic activities (tourism, trade, entrepreneurship) and the emergence of new players and ideas involved in ongoing spatial transformations, in both rural and urban spaces. Many changes were initiated in Iranian society and economy in the last decade or earlier (Coville, 2007), challenging preconceptions on this country (Adelkhah, 2013). The most common hypothesis at the time was that the lift of the sanctions would have multiple effects on every scale in terms of spatial reconfiguration, land ownership, 
construction, large urban projects and infrastructure, business and tourism. But unfortunately, to this day, the lift of the sanctions still remains to be completed and challenges are still present.

\section{The geographies of Iran. From area studies to cross- disciplinary developments}

6 This thematic issue aims to focus on the geographic dimension of studies on contemporary Iran. Geography has so far been a neglected area in the various academic traditions that form part of the vast cross-disciplinary field of area studies referred to as "Iranian studies", structured by academic congresses and associations, editorial collections and specialized journals such as Studia iranica or Iranian Studies (Hourcade et Richard, 1993). In this very international field (which is active in Iran as well as in the English-language, French and German academic worlds), which has a strong rooting in Persian language and civilization studies, some disciplines are well represented, such as history and historical geopolitics (Digard, Hourcade and Richard, 2007 [1996]), anthropology (Digard, 1981; 1988; Bromberger, 1998), political anthropology in particular on Shiism (Richard, 1980; Mervin, 2007), economics (Coville, 2000), as well as archaeology (Mousavi and Naseri-Moghaddam, 2009), art history and linguistics.

7 A cross-disciplinary field such as international relations has of course had a certain predilection for this country, which is located at the heart of what was referred to as the "Middle Eastern chessboard" or the "Grand Jeu" in the early twentieth century, and has undergone constant evolutions, in particular in the context of the oil trade (Djalili, 2005; Giblin, 2018). It is a fact that the revolution experienced by this country has had a major impact on world history. This revolution remains one of the few that established a lasting post-revolutionary situation (almost four decades) and led to the implementation of social policies independently from the theocratic dimension (Harris, 2017). In addition, Iran went through a war that remains the longest in the twentieth century. To this day, Iran is tying and untying potential alliances, whether those are new or reactivated, in an increasingly multi-centric world. Iran is trying to assert itself as a regional power, against competing countries like Turkey or Saudi Arabia, and great powers like the USA and Russia, which all are all contributing in this new century to reactivating the "Grand Jeu" of the Middle East ${ }^{1}$.

8 Finally, few geographers have studied Iran, and there are few monographs on the country's general or regional geography (Kiyâni Haftlang, 2003). Physical geography and more generally geophysics have documented the question of natural hazards, including chiefly seismic hazards. In France, Bernard Hourcade produced original analyses, in particular on urban growth, as well as a notable contribution to mapping studies with two definitive atlases of the whole country and the capital Tehran (Hourcade, 1998; 2003; Habibi and Hourcade, 2005).

9 Just like many other disciplines in social science since the dissemination of postmodern critique, geography is increasingly structured by cross-disciplinary fields. In this context, we must take into consideration the recent revival of migration studies and urban studies, which combine geography with urban geography, urban anthropology, cultural studies and political economics (Moghaddari, 2015; Moghadam, 2013; Malek, 2015). 
10 contexts and in more or less academic research environments, with various degrees of connection with independent researchers or artists, scholarship on Iran has integrated the contribution of these new thematic (new objects of studies) and theoretical (new interpretative frameworks) approaches. The interviews presented in the other sections of this issue attempt to provide an overview of the richness of cross-disciplinary approaches on Iranian society and urban production, which do not necessarily come from the academic world. On the articulation between anthropology and political economy, writings such as Fariba Adelkhah's (2012) on Iranians travelling abroad have contributed to reinventing the anthropology of mobility, exploring the interpretation of the idea of nation in depth based on the case of Iran. This work forms part of a broader movement in social science, which goes beyond methodological nationalism and focuses on the transnational dimension of the formation of national and territorial identity (Kashani-Sabet, 1999; Keddie and Matthee, 2002; Amanat and Veidani, 2012; Stone, 2014; Chehabi, Jafari and Jofroudi, 2015).

11 This question of the "imagined community", to quote B. Anderson, is tackled by Alice Bombardier, who explores the construction of Iran's national and territorial identity through a little-studied but essential angle: her paper examines how the teaching of geography in school builds up a sense of national identity. By comparing school textbooks published between 1973 and 1992, she questions representations of geographic space, and in particular maps which are overrepresented in school iconographies. Bombardier shows how maps reveal the policies that aimed to construct an imagined community, rooted in the nation-State's territory, to serve first the purposes of imperial ideology and later those of the cultural revolution and of patriotism - with respect to themes such as minorities and multilingualism, towncountry relations, or new perceptions of the capital Tehran and of the rest of the world. These maps' "insular" and "autarcic" quality, strongly rooted in regional heritage and stereotypes, denotes an opposition to the monarchic past and to Western hegemony, as well as a non-Western vision of the world.

\section{State reform and neo-liberalization: focussing on practices} the capital, Tehran. Examples include research projects that combine urban anthropology, architecture, urbanism and visual methodologies, bringing a fresh approach to topics such as transport, urban governance or participation in workingclass neighborhoods (Saïdi-Sharouz and Habibi, 2010; Saïdi-Sharouz, 2013). In particular, several research projects were conducted on female experiences of public spaces, revealing original connections between feminism and public space (Adelkhah, 2000; Kian-Thiébaut, 2002 and 2010; Amir-Ebrahimi, 2009; Saïdi-Sharouz and GuérinPace, 2011; Direnberger, 2011).

13 Research projects continue to build up field studies on Iranian men and women's spatial practices, including mobility or socio-cultural practices. By using practices as an entry point, these studies reveal multiple forms of adaptation and creativity in response to constraint and opportunity, depending on contexts and social groups - a phenomenon referred to by J.-F. Bayart (2010) as "the autonomy of the social". The 
interface between the sociological and geographic dimensions of cultural practices and policies is particularly well represented (Sreberny and Torfeh, 2016). The geography of cultural practices is one of many indicators of the cross-scalar relations between Iran, its urban spaces and the rest of the world. Fields studied in this perspective include theatre and literature (Nanquette, 2017), the visual arts and the role of the avant-garde arts scene in spatial transformations (Grigor, 2014; Bombardier, 2012), as well as cinema (Bagheri, 2012 Devictor, 2013). These studies document the creation of new norms that act as social markers of space, and as an inverted mirror for spaces of marginality and illegality - with examples including drugs (Ghiabi, 2018).

These norms can also apply to consumption and access to a certain lifestyle. Mina Saïdi-Sharouz's study presented in this issue analyzes a specific transformation in Tehran: the geography of retail (in particular furniture and home decoration stores), as well as the production of commercial spaces (in the city center and the periphery) and residential spaces (purpose-built developments). Saïdi-Sharouz shows how the evolution of the Iranian households' tastes, values and aspirations in terms of housing, furniture and decoration is inspired by the dissemination of marketing models and techniques through Turkish soap operas on television. These programs, which appear as a compromise between Westernization and tradition, are a cause for the extensive circulation of people and goods between the two countries.

These approaches share one common narrative which, contrary to assumption, is not so much an Iranian specificity as a particular variation of the global neoliberalization process: a combination of State reforms (de-centralization, autonomy of urban policies, public spending cuts, blurred boundaries between the public and private sectors) with a rise of interest and revenue in sub-contracting and local development projects, along with the growing role played by consumption and security in the management of space. In other words, Iran provides a very interesting variety of contemporary political economy (Harris, 2013; Khatam, 2015; Khatam and Keshavarzian, 2016; Vahabi and Coville, 2017).

Ronan des Vallières' contribution to this issue is a perfect illustration of this phenomenon. Des Vallières looks at a paradox: the proliferation of malls and shopping centers in Tehran, and the non-viability of the great majority of them. These commercial spaces are disconnected from any commercial or entrepreneurial activity, and are essentially financial assets in a market that has been dominated by speculation for the past few decades. The strategies of private (promoters and investors) and public (departments of state, municipalities and planners) stakeholders are so closely interlinked, in particular in terms of taxation and tax exemptions, that we could talk of a "continuum" between para-public and para-private sectors, which came as a result of pseudo-privatization policies. This is a particularly eloquent illustration of the financialization of real estate, or of the urbanization of capital.

\section{Poverty and vulnerability: residential mobility in city- country relations}

17 Investigating the definition of the middle class in a country where this class is for the most part post-revolutionary can shed a new light on this very notion, as the postrevolutionary period brought about a mass democratization of access to education and higher education. There are few examples in world history of such a stable post- 
revolutionary situation, which facilitated the emergence of a large new middle class. Nevertheless, Iran's post-revolutionary situation remains complex to sum up. First of all because, although poverty and illiteracy have considerably receded since the seventies, they are still present and visible in rural areas, peripheral provinces and poor neighborhoods. This phenomenon is all the more striking and concerning that the most vulnerable fringes of the middle class, along with the poor, have been hardly hit by pauperization in the early 2000 s.

In this context of real estate tension in urban areas, it is particularly interesting in the case of Iran to investigate the poorer neighborhoods, the social housing stock and how these are managed by public policies. The poor neo-urban populations who live in precarious conditions in the South and the periphery of Tehran form a social group whose mobilization has played a major political part during the revolution (Hourcade and Khosrokavar, 1983; Hourcade, 1997; Saïdi-Sharouz, 2013; Parsapajouh, 2016). In terms of mentalities, urban Iran and villages are characterized by distinct territorial value systems, although these differences have been blurred by rural exodus and urban sprawl.

In this issue, Amir Amiri presents a case study that confirms and brings a fresh perspective to these interactions between cities and country in Iran in the context of poverty. The rural exodus to large cities, in particular to Tehran, has indeed connected the country with urban resources, but it has also deprived the villages from their workforce. In parallel, A. Amiri shows that immigration - Iran is also a country of immigration, mostly from Afghanistan - does not only affect large cities. Based on his field work in villages of the North West of the country, A. Amiri shows that Afghani people find jobs in rural towns and contribute to reviving these areas, thus illustrating the complementarity between domestic and international migration. The pauperization of the most vulnerable households is patently linked to the toughening of economic sanctions in the mid-2000s. It is also due to drastic cuts in public spending and to a particular form of neo-liberalization. As in many other countries, the domestic economic policy has slipped towards more flexibility, subcontracting and public service commissioning, and more generally towards a reduction of welfare state expenditure and benefits. Although this process has taken on a particular form, it can be seen as a neo-liberalization of the state - a phenomenon referred to by Harris (2013) as the "subcontractor state". This context also explains the main trend in urban policies and large-scale redevelopment or construction projects which, as in other sectors, are delivered through partnerships between the public and the private sector (Khatam, 2015). This specific balance between the two illustrates what J.-F. Bayart (2010) described as a "Thermidorian situation", characterized by a mix of private capitalism, State capitalism and "administrative resources", combined with a unique intersection between the economic, administrative and military elites.

21 These elements of context explain why the study of Iran can provide original insights into notions that have been developed elsewhere and have considerably renewed the usual thematic approaches of social science: those include notions such as gentrification, urban activists, connections between research and artistic practice, etc. In particular, a significant correlation remains between political issues and citymaking. 


\section{BIBLIOGRAPHY}

Adelkhah F., 2000. La révolution sous le voile. Femmes islamiques d'Iran. Paris, Karthala, 280 p.

Adelkhah F., 2001. Les Iraniens de Californie : si la République islamique n'existait pas... Paris, Sciences-Po, CERI, Les Études du CERI, 75, 40 p.

Adelkhah F., 2012. Les mille et une frontières de l'Iran, quand les voyages forment la nation. Paris, Karthala, 492 p.

Adelkhah F., 2013. Les paradoxes de l'Iran. Idées reçues sur la République islamique. Paris, Le Cavalier bleu, $237 \mathrm{p}$.

Amanat A., Vejdani F. (ed.), 2012. Iran Facing Others: Identity Boundaries in a Historical Perspective. New York, Palgrave Macmillan, 292 p.

Amir-Ebrahimi M., 2009. Mme Gohari, la dame des quartiers sud de Téhéran. La pensée de midi, 27, p. 33-40.

Bagheri A., 2012. Les relations homme/femme dans le cinéma iranien postrévolutionnaire, stratégies des réalisateurs, analyse sémiologique. Thèse de doctorat en linguistique et sémiologie, Université René Descartes - Paris V, 376 p.

Bayart J.-F., 2010. La République islamique d'Iran dans la tourmente. Études, tome $413, \mathrm{n}^{\circ} 7$, P. 7-17.

Bombardier A., 2012. Peinture de guerre et représentations anthropomorphiques dans un lieu de prière musulman en Iran. Asiatische Studien, 66-3, p. 565-598.

Bromberger C., 1998. Le football en Iran. Sociétés \& Représentations, 7, p. 101-115.

Chehabi, H. Jafari P., Jefroudi M. (dir.), 2015. Iran in the Middle East. Transnational Encouters and Social History. Londres, Tauris, $336 \mathrm{p}$.

Colby A., Friedlander J. Kelley R., 1993. Irangeles. Iranians in Los Angeles. Oakland, University of California Press, 396 p.

Coville T., 2000. Ordre monétaire et désordres économiques en Iran depuis la révolution islamique. Thèse de doctorat en sciences économiques, Nanterre, Université Paris X, 224 p.

Coville T., 2007. Iran, la révolution invisible. Paris, La Découverte, 264 p.

Devictor A., 2013. Politique du cinéma iranien De l'âyatollâh Khomeyni au président Khâtami. Paris, CNRS Éditions, 310 p.

Digard, J.-F. (ed.), 1988, Le fait ethnique en Iran et en Afghanistan. Paris, CNRS, 301 p.

Digard, J.-F., 1981, Techniques des nomades Baxtyâri d'Iran. Paris-Cambridge, Maison des sciences de l'Homme et Cambridge University Press, $273 \mathrm{p}$.

Digard, J.-F., Hourcade B., Richard Y., 2007 [1996]. L'Iran au XX ${ }^{\mathrm{e}}$ siècle. Paris, Fayard, 498 p.

Direnberger L., 2011. De la rue à Internet : espaces de contestation féminins et féministes à Téhéran. Justice spatiale Spatial justice, 3 [Online]. http://www.jssj.org

Djalili M.-R., 2005. Géopolitique de l'Iran. Bruxelles, Complexe, 144 p.

Djalili M.-R., Kellner T., 2016. Iran : la nouvelle puissance régionale ? Iran le retour. Questions internationales, 77, p. 4-21. 
Ghiabi M., 2018. Drogues illégales et gestion de l'espace dans l'Iran moderne. Hérodote, n 169, p. 133-151. DOI:10.3917/her.169.0133

Giblin B. (dir.), 2018. Regards géopolitiques sur l'Iran. Hérodote, 169. 151 p.

Grigor T., 2014. Contemporary Iranian Art: From the Street to the Studio. Londres, Reaktion Books, $256 \mathrm{p}$.

Habibi M., Hourcade B., 2005. Atlas de Téhéran métropole/Atlas of Tehran Metropolis/Atlas-E Kalânshahr-E Tehrân. Vol. 1. La terre et les hommes/Land and people/Sarzamin va mardom. Téhéran, Centre d'informations géographiques de Téhéran (TGIC), 218 p. (en persan), 79 p. (en français), 75 p. (en anglais), 214 cartes.

Harris K., 2013. The Rise of the Subcontractor State: Politics of Pseudo-Privatization in the Islamic Republic of Iran. International Journal of Middle East Studies, vol. 45, n 1, p. 45-70. DOI : $10.1017 /$ S0020743812001250

Harris K., 2017. A Social Revolution : Politics and the Welfare State in Iran. Oakland, University of California Press, 336 p.

ourcade B., 1997. L'émergence des banlieues de Téhéran. Cahiers d'études sur la Méditerranée orientale et le monde turco-iranien [Online], $\mathrm{n}^{\circ} 24$. http://journals.openedition.org/cemoti/1472

Hourcade B. (ed.), 2003. Iran, questions et connaissances. Vol. III. Cultures et sociétés contemporaines. Louvain-Paris, Peeters et Association pour l'avancement des études iraniennes, $318 \mathrm{p}$.

Hourcade B. et al., 1998. Atlas d'Iran. Montpellier-Paris, Reclus et La Documentation française, $192 \mathrm{p}$.

Hourcade B., Khosrokhavar K., 1983. L'habitat révolutionnaire à Téhéran, 1977-1981. Hérodote, 31, p. 62-83.

Hourcade B., Richard Y., 1993. Les études iraniennes en France. Téhéran, Institut français de recherche en Iran, 90 p. (en français), 58 p. (en persan).

Kashani-Sabet F., 1999. Frontier Fictions: Shaping the Iranian Nation, 1804-1946. Princeton, Princeton University Press, 304 p.

Keddie N. R., Matthee R. P. (ed.), 2002. Iran and the Surrounding World: Interactions in Culture and Cultural Politics. Seattle, University of Washington Press, 408 p.

Khatam A., 2015. Tehran Urban Reforms between Two Revolutions, Developmentalism, Worlding Urbanism and Neoliberalism. Thèse de doctorat, York, Faculty of Environmental Studies, York University, 197 p.

Khatam A., Keshavarzian A., 2016. Decentralization and Ambiguities of Local Politics in Tehran. Middle East Institute, Governing Megacities in MENA and Asia. http://www.mei.edu/content/ map/governing-megacities-mena-and-asia

Kian-Thiébaut A., 2002. Les femmes iraniennes entre Islam, État et famille. Paris, Maisonneuve \& Larose, $318 \mathrm{p}$.

Kian-Thiébaut A., 2010. Le féminisme islamique en Iran : nouvelle forme d'assujettissement ou émergence de sujets agissants? Critique internationale, 46, p. 45-66.

Kiyâni Haftlang K., 2003. The Book of Iran: A Survey on the Geography of Iran. Téhéran, Center for International Cultural Studies, $107 \mathrm{p}$. 
Malek A., 2015. Claiming Space: Documenting Second-Generation Iranian Americans in Los Angeles. Anthropology of the Middle East, vol. 13 (2), p. 16-45.

Mervin S., 2007. Les mondes chiites et l'Iran. Paris-Beyrouth, Karthala et IFPO, 484 p.

Moghadam A., 2013. Un espace social transnational entre les Émirats et le sud de l'Iran : les Khodmouni (Lârestâni) à Dubaï. EchoGéo, 25 [en ligne]. http://echogeo.revues.org/13554 DOI : 10.4000/echogeo.13554

Moghadam A., 2016. Tensions diplomatiques irano-arabes et pérennité de la présence des Iraniens à Dubaï. Confluences Méditerranée, 97, p. 63-77.

Moghadam A., Weber S., 2015. Les Iraniens à l'étranger, une composante de la société iranienne. In Moghadam A. et Weber S. (ed.), Diasporas iraniennes. Hommes et migrations [en ligne], 1312. http://www.hommes-et-migrations.fr/index.php?/numeros/l-iran-une-puissance-diasporique/ 7713-les-iraniens-a-l-etranger-une-composante-de-la-societe-iranienne

Moghaddari S., 2015. Migrations et modernités iraniennes. Les familles transnationales. ParisTéhéran, Éditions du Cygne et IFRI, 172 p.

Mohabbat-Kar R., 2015. Introduction. In Mohabbat-Kar R. (ed.), 2015. Identity and Exile. The Iranian Diaspora between Solidarity and Difference. Berlin, Heinrich Böll Foundation, 148 p.

Mousavi A., Nasiri-Moghaddam N., 2009. Les hauts et les bas de l'archéologie en Iran. La pensée de midi, $\mathrm{n}^{\circ} 27$, p. 137-143.

Naficy H., 1993. The Making of Exile Cultures, Iranian Television in Los Angeles. Minneapolis, University of Minnesota Press, 283 p.

Nanquette L., 2017. The Global Circulation of an Iranian Bestseller. Interventions, vol. 19, $\mathrm{n}^{\circ} 1$, p. 56-72.

Parsapajouh S., 2016. Au cœur d'un bidonville iranien : de Zurâbâd à Islamabâd. Paris-Téhéran, Karthala et IFRI, $361 \mathrm{p}$.

Richard Y., 1980. Le Shi'isme en Iran. Imam et révolution. Paris, Maisonneuve, 135 p.

Saïdi-Sharouz M. (ed.), 2013. Le Téhéran des quartiers populaires. Transformations urbaines et société civile en République islamique. Paris-Téhéran, Karthala et IFRI, 272 p.

Saïdi-Sharouz M., Guerin-Pace F., 2011. La mobilité quotidienne des femmes dans la ville de Téhéran : entre visibilité et invisibilité. L'Espace géographique, tome 40, n² 2, p. 176-188. DOI : 10.3917/eg.402.0176

Saïdi-Sharouz M., Habibi M., 2010. Banlieues sud de Téhéran : L'autoproduction de lieux publics. Urbanisme, 374, p. 35-38.

Salehi-Isfahani D., 2017. Poverty and Income Inequality in the Islamic Republic of Iran. Revue internationale des études du développement, 229, p. 113-136. https://doi.org/10.3917/ried. 229.0113

Sreberny A., Torfeh M. (ed.), 2016. Cultural Revolution in Iran: Contemporary Popular Culture in the Islamic Republic. Londres, New York, Tauris, 288 p.

Stone L. (ed.), 2014. Iranian Identity and Cosmopolitanism: Spheres of Belonging. Londres New York, Bloomsbury, $256 \mathrm{p}$.

Vahabi M., Coville T. (dir.), 2017. L'économie politique de la république islamique d'Iran. Revue internationale des études du développement, 229, $182 \mathrm{p}$. 


\section{NOTES}

1. See for instance thematic issue Moyen-Orient : le nouveau "Grand jeu ", Politique étrangère, vol. 81, $\mathrm{n}^{\circ} 2$, Paris, Institut français des relations internationales.

INDEX

Subjects: Sur le Champ - Sur le Terrain

\section{AUTHORS}

\section{AMIN MOGHADAM}

Amin Moghadam is a geographer at the Centre d'études sur le golfe Persique et l'Iran à

l'Université de Princeton aux États-Unis. He recently published:

- Moghadam A., Brones S. (dir.), 2016. Marchés et nouveaux territoires de l'art dans les villes du Sud, Géographie et Cultures, $n^{\circ} 97$ [En ligne]. https://journals.openedition.org/gc/4248

- Moghadam A., Weber S., 2017. Circulating by default. Yerevan and Erbil, the backyards of Iranian mobility. In Vignal L. (dir.), Transnational Middle East. Places, People, Frontiers. Londres, Routledge.

- Moghadam A., 2016. Tensions diplomatiques irano-arabes et pérennité de la présence des Iraniens à Dubaï. Confluences Méditerranée, 2016/2, № 97, p. 63-77.

\section{MINA SAIIDDI-SHAROUZ}

Mina Saïdi-Sharouz, minasaidi@yahoo.com, is an architect and a geographer. A teacher at the École Nationale Supérieure d'Architecture de Paris-La Villette (ENSAPLV), she is a member of the Laboratoire Architecture Anthropologie (LAVUE/CNRS) and the Association Relief. She He recently published:

- Saïdi-Sharouz M., 2018. L'intégration des migrants dans le centre de Téhéran. La communauté des Ramshehi à Cyrus. In Raulin A., Parsapajouh S. et Blanc-Chaléard M.C. (dir.), Ces villes-là. Actualité de Colette Pétonnet. Paris, Presses Universitaires de Paris Nanterre, p. 135-158. - Saïdi-Sharouz M., 2015. Les touristes iraniens à Istanbul, les fourmis voyageuses de la mondialisation. Hommes \& Migrations, 2015/4, n 1312, p. 81-89.

- Saïdi-Sharouz M. (dir.), 2013. Le Téhéran des quartiers populaires. Transformation urbaine et société civile en République Islamique. Paris, Karthala-IFRI, 265 p.

\section{SERGE WEBER}

Serge Weber, serge.weber@u-pem.fr, University Professor, University of Paris-Est Marne-laVallée and member of the Comparative Power Analysis Laboratory. He recently publihed: - Moghadam A., Weber S., 2016. Circulating by default: Erbil and Erevan, the Backyards of Iranian Mobility. In Vignal L. (dir.), Transnational Middle East: Places, Peoples and Borders. Londres, Routledge, p. 164-180.

- Moghadam A., Weber S. (dir.), 2016. Diasporas iraniennes. Hommes et migrations, nº 1312. 
- Hancock C., Lelévrier C., Ripoll F., Weber S. (dir.), 2016. Discriminations territoriales. Paris, L'œil d'or, $272 \mathrm{p}$. 